\title{
Mediasi Pidana dalam Ketentuan Hukum Pidana Adat
}

\author{
Trisno Raharjo \\ Fakultas Hukum Universitas Muhammadiyah Yogyakarta \\ Jl. Lingkar Selatan Kasihan Bantul Yogyakarta \\ trisnoraharjo@umy.ac.id
}

\begin{abstract}
This research focused to dispute resolution through negotiation in "Adat" Law. This research operates in "adat" community of Banjar, Aceh, Ambon, North Lombok, and Lamaholot. The researched question is penal mediation as conflict resolution between perpetrator and victim of criminal conduct. Using normative, conceptual, and historical approach, this research reveals negotiation becomes the basis conflict dispute between perpetrator and victim. Negotiation inspired the development of criminal mediation which is known as traditional village or tribal moots.
\end{abstract}

Key words : Criminal Mediation, "adat" penal law, "adat" community

\begin{abstract}
Abstrak
Penelitian ini mengkaji penyelesaian konflik secara musyawarah untuk secepat mungkin diadakan perdamaian berkembang sebagai hukum adat. Masalah yang diteliti adalah mediasi sebagai penyelesaian konflik antara pelaku tindak pidana dan korban tindak pidana dalam masyarakat adat di Indonesia. Penelitian ini menggunakan penelitian hukum normatif, yang menekankan pada studi dokumen dalam penelitian kepustakaan untuk mempelajari data sekunder di bidang hukum yang berhubungan dengan permasalahan dan tujuan penelitian ini. Pendekatan yang digunakan adalah pendekatan konseptual dan pendekatan historis. Penelitian ini menyimpulkan, bahwa penyelesaian konflik antara pelaku tindak pidana dan korban tindak pidana dalam masyarakat adat di Indonesia, merupakan bentuk pendekatan mediasi pidana yang dikenal sebagai traditional village or tribal moots. Hasil penelitian ini menunjukkan bahwa penyelesaian hukum adat diakui sebagai inspirasi bagi banyak program mediasi modern dan termasuk untuk mediasi pidana.
\end{abstract}

Kata kunci : Mediasi pidana, hukum pidana adat, masyarakat adat 


\section{Pendahuluan}

Berdasarkan penelitian yang dilakukan oleh berbagai kalangan akademisi terhadap penyelesaian konflik dalam masyarakat di Indonesia, pada dasarnya budaya untuk penyelesaian secara musyawarah atau konsiliasi merupakan nilai yang banyak dianut oleh masyarakat di Indonesia. Berbagai suku bangsa di Indonesia mempunyai budaya penyelesaian konflik secara damai, misalnya masyarakat Jawa, Lampung, Bali, Sumatra Selatan, Lombok, Papua, Sulawesi Barat, dan masyarakat Sulawesi Selatan. ${ }^{1}$

Penyelesaian konflik secara musyawarah untuk secepat mungkin diadakan perdamaian berkembang sebagai hukum adat. Perkembangan selanjutnya dari hukum adat pada suku bangsa di Indonesia khususnya terhadap penyelesaian konflik melalui musyawarah memiliki berbagai kesamaan yaitu konflik diarahkan pada harmonisasi atau kerukunan dalam masyarakat serta tidak memperuncing keadaan, dengan sedapat mungkin menjaga suasana perdamaian. ${ }^{2}$

Penyelesaian-penyelesaian konflik yang dilakukan melalui mekanisme hukum adat baik untuk perkara perdata maupun perkara pidana. Berbeda dengan hukum pidana barat, tujuan hukum pidana adat adalah memulihkan keseimbangan hukum yang menjadi tujuan segala reaksi atau koreksi adat sedangkan tujuan untuk memperbaiki orang yang salah, orang yang melanggar hukum, sebagai salah satu dasar yang terdapat pada sistem hukum pidana barat, tidak terdapat pada sistem hukum adat. $^{3}$

Penyelesaian konflik secara musyawarah guna mencapai penyelesaian antara pelaku dan korban tindak pidana sebagian besar masyarakat di Indonesia yang umumnya beragama Islam, banyak memperoleh pengaruh dari hukum Islam. Konflik-konflik dalam masyarakat banyak dimintakan penyelesaiannya kepada tokoh masyarakat, dan umumnya pada daerah-daerah yang pengaruh hukum Islamnya kuat, seperti di Aceh, Sumatra Barat, dan Jawa maka para tokoh masyarakat atau adat di dalamnya termasuk para tokoh-tokoh agama. Penyelesaian konflik yang diselesaikan oleh tokoh-tokoh agama Islam umumnya dilakukan dengan pendekatan

\footnotetext{
${ }^{1}$ Ahmadi Hasan, "Penyelesaian Sengketa Melalui Upaya (Non-Litigasi) Menurut Peraturan PerundangUndangan” dalam Jurnal Al-Banjari, Vol. 5, No. 9, Januari-Juni 2007, hlm. 5.

${ }^{2}$ Sudargo Gautama, "Penyelesaian Sengketa Secara Alternatif (ADR)," dalam Hendarmin Djarab, et al, (Editor), Prospek dan Pelaksanaan Arbitrase di Indonesia Mengenang Alm. Prof. Dr. Komar Kantaatmadja, S.H., LL.M., Citra Aditya Bakti, Bandung, 2001, hlm. 124.
} 
musyawarah. Menurut Hazairin penyelesaian yang dilakukan oleh tokoh agama Islam yang dilakukan secara terus-menerus sehingga menjadi tradisi membentuk hukum adat dalam masyarakat tersebut, dalam hal ini adalah hukum Islam yang telah dipraktekkan selama berabad-abad semenjak Islam dipeluk oleh masyarakat Indonesia. ${ }^{4}$

Budaya musyawarah, sebagai sistem nilai yang dihayati oleh masyarakat Indonesia, merupakan semangat untuk masing-masing pihak yang berunding di dalam musyawarah tersebut untuk menyelesaikan konflik misalnya, akan berupaya mengurangi pendiriannya sehingga dapat dicapai titik temu yang menguntungkan bagi semua pihak, yang berujung pada mufakat. Suatu musyawarah memerlukan tokoh yang dihormati untuk memimpin musyawarah dapat mencapai mufakat tersebut. Apa yang diputuskan dalam musyawarah guna menyelesaikan konflik tersebut secara perlahan-lahan berkembang menjadi hukum adat. ${ }^{5}$

\section{Rumusan Masalah}

Dalam studi ini akan dikaji dan dibahas tentang bagaimana mediasi sebagai penyelesaian konflik antara pelaku tindak pidana dan korban tindak pidana dalam masyarakat adat di Indonesia?

\section{Tujuan Penelitian}

Tujuan dari studi ini dimaksudkan untuk mengkaji dan menganalisis mediasi sebagai penyelesaian konflik antara pelaku tindak pidana dan korban tindak pidana dalam masyarakat adat di Indonesia.

\section{Metode Penelitian}

Penelitian ini menggunakan penelitian hukum normatif, yang menekankan pada studi dokumen dalam penelitian kepustakaan untuk mempelajari data sekunder di bidang hukum yang berhubungan dengan permasalahan dan tujuan penelitian ini.

\footnotetext{
${ }^{4}$ Hazairin dalam Siti Juwariyah, Potret Mediasi dalam Islam, dalam http://www.badilag.net, diakses 20 Desember 2009.

${ }^{5}$ Adi Sulistiyo, Mengembangkan Paradigma Non-Litigasi di Indonesia, Sebelas Maret University Press, Surakarta, 2006, hlm. 367-369
} 
Pendekatan yang digunakan adalah pendekatan konseptual dan pendekatan historis. ${ }^{6}$ Pendekatan konseptual dalam penelitian ini dimaksudkan untuk mencari dasar mediasi pidana yang berasal dari asas-asas hukum yang relevan serta doktrin-doktrin hukum adat. Pendekatan historis dilakukan dalam kerangka pelacakan penerapan mediasi pidana dalam hukum adat di Indonesia. Mengingat luasnya wilayah Indonesia dan beraneka ragamnya masyarakat adat di Indonesia maka penelitian ini akan memfokuskan pada masyarakat adat Banjar, masyarakat adat Dayak di Kalimantan Tengah, masyarakat adat Aceh, masyarakat adat Ambon, masyarakat adat Lombok Utara, masyarakat adat Lamaholot di Flores Nusa Tenggara Timur dengan pertimbangan persebaran wilayah serta dapat mencakup keragaman penyelesaian konflik dalam hukum adat.

Penelitian ini menekankan pada data sekunder yang terdiri dari bahan hukum primer berupa ketentuan-ketentuan hukum adat yang terdokumentasi, ${ }^{7}$ bahan hukum sekunder yang diperoleh dari buku teks, jurnal, kasus-kasus hukum. Prosedur pengumpulan bahan hukum dilakukan melalui studi literatur dan studi dokumen sesuai dengan permasalahan yang telah dirumuskan untuk selanjutnya dikaji secara komprehensif. Pengolahan dan Analisis Bahan Hukum dilakukan dengan metode dogmatik hukum yaitu bahan hukum primer dilakukan dengan cara memahami teks dari bahan hukum kemudian dikaitkan dengan isi pengertian teks yang satu dengan yang lain yang menggambarkan penyelesaian konflik melalui mediasi pidana antara pelaku dan korban tindak pidana dalam hukum adat.

\section{Hasil dan Pembahasan}

Mediasi pidana menurut Martin Wright adalah:8 " a process in which victim(s) and offender(s) communicate with the help of an impartial third party, either directly (faceto-face) or indirectly via the third party, enabling victim(s) to express their needs and feelings and offender(s) to accept and act on their responsibilities." ["Suatu proses di mana korban dan pelaku kejahatan saling bertemu dan berkomunikasi dengan bantuan pihak ketiga baik secara langsung atau secara tidak langsung dengan menggunakan

\footnotetext{
${ }^{6}$ Peter Mahmud Marzuki, Penelitian Hukum, Kencana, Jakarta, 2005, hlm. 93

${ }^{7}$ Soerjono Soekanto memasukkan hukum adat sebagai bahan hukum yang tidak dimodifikasi dalam kategori bahan hukum primer, lihat selanjutnya Soerjono Soekanto dan Sri Mamudji, Penelitian Hukum Normatif, Rajawali, Jakarta, 2010, hlm. 13

${ }^{8}$ Martin Wright sebagaimana dikutib oleh Marc Groenhuijsen, Victim-Offender-Mediation: Lagal And Procedural Safeguards Experiments And Legislation In Some European Jurisdictions, Leuven, Oktober 1999, hlm. 1.
} 
pihak ketiga sebagai penghubung, memudahkan korban untuk mengekspresikan apa yang menjadi kebutuhan dan perasaannya dan juga memungkinkan pelaku menerima dan bertanggung jawab atas perbuatannya."]

Meskipun pengadilan dibentuk oleh negara untuk menyelesaikan konflik yang muncul dalam masyarakat dan bersifat netral, tetapi pengadilan bukanlah satusatunya institusi dalam menyelesaikan konflik, karena pihak-pihak yang berkonflik tidak selamanya menggunakan mekanisme penyelesaian pada badan peradilan. ${ }^{9}$

Marc Galanter menyatakan pencarian keadilan tidak hanya di dapatkan di ruang pengadilan akan tetapi juga terdapat di luar ruang pengadilan. ${ }^{10}$ Penyelesaian konflik antara pelaku dan korban tindak pidana tidak hanya diselesaikan dalam sistem peradilan pidana sebagai penyelesaian formal akan tetapi dalam masyarakat Indonesia penyelesaian secara hukum adat juga menjadi cara penyelesaian konflik. Hukum adat adalah hukum asli Indonesia yang tidak tertulis atau tidak tertuang di dalam bentuk perundang-undangan Republik Indonesia dan disana-sini mengandung unsur agama. ${ }^{11}$

Berdasarkan rekomendasi Dewan Eropa Nomor R (99) 19 tentang Mediation in Penal Matters sebagaimana termuat dalam Explanatory memorandum, terdapat salah satu model mediasi pidana adalah traditional village or tribunal moots, menurut model ini, seluruh masyarakat bertemu untuk mencegah konflik kejahatan di antara warganya. Model ini telah ada sebelum terbentuknya hukum barat. Karena karakteristik model ini lebih tepat diterapkan pada masyarakat gemeinschaft, ${ }^{12}$ maka sampai saat ini masih diterapkan di negara-negara berkembang khususnya di daerah pedesaan. Penyelesaian dengan pendekatan model ini senantiasa diarahkan untuk memberikan keuntungan bagi masyarakat secara luas. Meskipun model ini tampaknya tidak tepat untuk diterapkan pada masyarakat moderen atau masyarakat dengan pola kehidupan perkotaan, akan tetapi model ini telah banyak memberikan kontribusi dan inspirasi bagi model mediasi modern. ${ }^{13}$

\footnotetext{
${ }^{9}$ Mudzakkir, "Posisi Hukum Korban Kejahatan dalam Sistem Peradilan Pidana", Disertasi, Program Pascasarjana FH UI, Jakarta, 2001

${ }^{10}$ Marc. Galanter, Keadilan di Berbagai Ruangan: Lembaga Peradilan, Penataan Masyarakat serta Hukum Rakyat dalam T.O. Ihromi (Penyunting), Antropologi Hukum sebuah Bunga Rampai, Yayasan Obor, Jakarta, 1993 , hlm. 81

${ }^{11}$ Rumusan Hukum Adat yang dihasilkan dalam seminar hukum adat dan pembinaan hukum nasional di Yogyakarta 15-17 Januari 1975 dalam Imam Sudiyat, Peran Pendidikan dalam Pembangunan Hukum Nasional Berlandaskan Hukum Adat, Liberty, Yogyakarta, 1980, hlm. 1.

${ }^{12}$ Masyarakat gemeinschaft adalah bentuk kehidupan bersama dimana anggota-anggotanya diikat oleh hubungan batin yang murni dan bersifat alamiah serta bersifat kekal. Lihat Soerjono Soekanto, Sosiologi Suatu Pengantar, Rajawali Pers, Jakarta, 1986, hlm. 119.

${ }^{13}$ Rekomendasi Dewan Eropa No R (99) 19, Op. Cit.
} 
Penyelesaian konflik perlu memperhatikan hukum adat yang berlaku di masyarakat. Sebab jika hukum adat masih sangat kuat dipertahankan dalam masyarakat maka mekanisme hukum adat akan menjadi faktor penentu keberhasilan penyelesaian konflik. Van Vollenhoven sebagaimana dikutip oleh Sudiman Kartohadiprodjo menyatakan: “Jika penguasa memutuskan akan mempertahankan hukum adat, padahal hukum itu sudah surut. Maka penetapan itu akan tiada guna. Sebaliknya, seandainya telah ditetapkan dari atas bahwa hukum adat harus diganti, sedangkan rakyat masih menaatinya, maka Hakim Negara sekalipun akan tidak berdaya menghadapinya. ${ }^{14}$

Suryono Sukanto menyatakan "hukum adat yang masih berlaku merupakan bagian dari hukum yang hidup ... hukum yang hidup merupakan bagian dari hukum nasional dan menjadi tujuan untuk dicapai, karena hukum yang hidup berlaku secara yuridis, sosiologis maupun filosofis. ${ }^{15}$

Apabila terjadi peristiwa pelanggaran pidana adat maka yang dilihat bukan semata-mata perbuatan dan akibatnya, tetapi, juga dilihat apa yang menjadi latar belakang dan siapa pelakunya. Dengan alam pikiran demikian, maka dalam cara mencari penyelesaian dan melakukan tindakan hukum terhadap suatu peristiwa menjadi berbeda-beda. ${ }^{16}$

Penyelesaian melalui mekanisme mediasi dalam konflik antara pelaku dan korban tindak pidana melalui hukum adat dapat diuraikan sebagai berikut:

\section{Penyelesaian Perkara Pidana Melalui Mediasi Pidana pada Masyarakat Adat Banjar}

Adat badamai adalah salah satu bentuk penyelesaian sengketa yang lazim dilakukan oleh masyarakat Banjar. Adat badamai bermakna sebagai hasil proses perembukan atau musyawarah dalam pembahasan bersama dengan maksud mencapai suatu keputusan sebagai penyelesaian dari suatu masalah. ${ }^{17}$ Putusan Badamai yang dihasilkan melalui mekanisme musyawarah merupakan upaya alternatif dalam mencari jalan keluar guna memecahkan persoalan yang terjadi dalam masyarakat. Masyarakat Banjar berkecenderungan menyelesaikan sengketa melalui adat badamai. Adat badamai diakui efektif dalam penyelesaian pertikaian atau sengketa. Sekaligus untuk menghilangkan perasaan dendam.

\footnotetext{
${ }^{14}$ Sudiman Kartohadiprodjo, Hukum Nasional, Beberapa Catatan, Binacipta, Bandung, 1971, hlm. 8.

${ }^{15}$ Suryono Sukanto, "Pembahasan dalam Seminar Hukum Adat dan Pembinaan Hukum Nasional" dalam Imam Sudiyat, Peran Pendidikan...., hlm. 5.

${ }^{16}$ Hilman Hadikusuma, Hukum Pidana Adat, Alumni,Bandung, tt, hlm. 13
} 
Adat badamai merupakan istilah bagi penyelesaian sengketa baik yang bersifat keperdataan maupun pidana. Adat badamai dalam penyelesaian sengketa pidana disebut juga dengan istilah Baparbaik dan Bapatut. ${ }^{18}$

Menurut hasil penelitian Ahmad Bahruni dari data kecelakaan lalu lintas yang terjadi di Banjarmasin selama 1995-2000 terjadi sebanyak 43 (empat puluh tiga) perkara kecelakaan lalu lintas. Sebanyak 25 (dua puluh lima) perkara lalu lintas diselesaikan secara badamai. Inisiatif penyelesaian diambil dari pihak pelaku atau keluarganya sebanyak 17 (tujuh belas) kasus, inisiatif diambil oleh pihak korban atau keluarganya sebanyak 5 (lima) kasus, dan inisiatif dilakukan oleh pihak kepolisian bersama keluarga korban sebanyak 3 (tiga) kasus. ${ }^{19}$

Melalui perundingan badamai maka dicapai kesepakatan secara umum dapat dibagi menjadi tiga yaitu: ${ }^{20}$ a. Korban mendapat bantuan biaya perawatan atau pengobatan, terdapat pada 15 (lima belas) kasus. ${ }^{21}$ b. Korban meninggal dunia, mendapat santunan berupa uang duka dari pihak penabrak, terdapat pada 6 (enam) kasus. ${ }^{22}$ c. Korban mendapat bantuan biaya perbaikan kendaraan dan biaya perawatan, terdapat pada 4 (empat) kasus.

\section{Penyelesaian Perkara Pidana Melalui Mediasi Pidana pada Masyarakat Adat Dayak, Kalimantan Tengah}

Peraturan Daerah Kotawaringin Timur Nomor 15/2001 tentang Kedamangan dan Peraturan Daerah Pulang Pisau Nomor 11/2003 tentang Pembentukan Kelembagaan dan Pemberdayaan Adat Dayak, mengharuskan setiap kedamangan harus mempunyai seorang damang sebagai pemimpin. ${ }^{23}$ Damang dan let adat-nya membentuk sebuah Dewan Adat. ${ }^{24}$

\footnotetext{
${ }^{18}$ Ahmadi Hasan, "Penyelesaian Sengketa Hukum Berdasarkan Adat Badamai pada Masyarakat Banjar dalam Kerangka Sistem Hukum Nasional”, Disertasi, Pascasarjana FH UII, 2007, hlm. 117

${ }^{19}$ Ahmad Bahruni, "Penyelesaian Tindak Pelanggaran Lalu-Lintas Secara Kekeluargaan, sebuah Tinjauan Menurut Hukum Islam dan Hukum Positif", dalam Ahmadi Hasan, "Penyelesaian Sengketa Hukum Berdasarkan Adat Badamai pada Masyarakat Banjar dalam Kerangka Hukum Nasional”, Disertasi, Pascasarjana S3 Program Doktor Ilmu Hukum, Universitas Islam Indonesia, 2007, hlm. 299

${ }^{20}$ Ibid. 300

${ }^{21}$ Biaya perawatan atau pengobatan sesuai dengan kesepakatan badamai mulai dari Rp 150.000,00

${ }^{22}$ Biaya uang duka sesuai dengan kesepakatan badamai paling besar Rp 7.500.000,00

${ }^{23}$ Tidak perlu ada keterkaitan dengan batas administratif, namun dalam praktek sebuah kedamangan biasanya mencakup wilayah kecamatan. Di bawah damang pada tingkat desa atau kelurahan ada perangkatnya, yang dikenal sebagai mantir atau let adat. Di atas damang, pada tingkat kabupaten terdapat Koordinator Adat Wilayah, yang dipilih dari para damang sendiri.

${ }^{24}$ Peri Umar Farouk, et.al, "Kembali ke Masa Depan: Otonomi Daerah dan Kebangkitan Adat yang Tidak Pasti." hlm. 4 <http://www.justiceforthepoor.or.id/ documents/publikasi/vja-kalteng.pdf>, diakses 17 Oktober
} 
Tugas utama demang antara lain mengawasi penerapan hukum adat dan memelihara institusi-institusi adat menyelesaikan perselisihan dan pelanggaran hukum adat memberi nasihat kepada pemerintah setempat yang berkaitan dengan hukum adat melestarikan dan mengembangkan kebudayaan penduduk asli mempromosikan nilai-nilai budaya Dayak. ${ }^{25}$

Berdasarkan tugas tersebut maka Adat harus menjadi tempat pertama bagi resolusi damai. Damang mempunyai otoritas untuk menyelesaikan baik kasus perdata maupun pidana. Keputusan adat dianggap "mengikat" pada pihak-pihak yang terlibat, namun putusan tersebut hanya menjadi "pertimbangan" bagi aparat hukum jika suatu sengketa diproses di sistem formal. Artinya keputusan secara adat tidak mencegah tindakan hukum formal. Pengadilan bebas mengabaikan hasil resolusi secara adat.

Perkara pembunuhan di Palangkaraya, diselesaikan melalui mediasi, salah satu motivasi pelaku tindak pidana menggunakan hukum adat adalah mengurangi hukuman penjara yang dijatuhkan oleh pengadilan. ${ }^{26}$ Selain itu dimaksudkan pula untuk memelihara kerukunan sosial, dan mediasi juga dianggap lebih murah dan lebih pasti dalam menyelesaikan konflik antara pelaku dan korban tindak pidana. ${ }^{27}$

Ketentuan hukum adat mencakup baik kasus perdata remeh maupun tindak pidana berat seperti pembunuhan dan perkosaan. Di bawah hukum adat, jika kedua belah pihak rela, semua masalah dapat diselesaikan dengan damai melalui konsiliasi.

Ketua Dewan Adat Kabupaten Kotawaringin Timur menjelaskan proses yang ia terapkan, yang secara umum menggambarkan proses resolusi sengketa, baik secara adat maupun non-adat di Kalimantan Tengah: ${ }^{28}$ a. Keluhan/keberatan diterima dalam bentuk tertulis atau lisan; b. Biaya perkara sekitar Rp100,000 dibayarkan kepadanya oleh pelapor. Ini mencakup makanan ringan untuk acara "persidangan" dan biaya operasional; c. Kemudian damang akan menelaah kasus, memeriksanya dahulu dengan kepala desa/let adat (jika ada) untuk melihat apakah upaya-upaya resolusi telah dilakukan di tingkat desa; d. Maka damang memanggil pihak-pihak yang terlibat dan saksi-saksi ke rumahnya untuk "persidangan"; e. Damang akan mengajukan sebuah resolusi atau membantu memediasi untuk mencapai kompromi. Jika pihak-pihak sepakat, hasil kesepakatan akan dicatat dan ditandatangani. Jika tidak, maka mereka

\footnotetext{
${ }^{25}$ Ibid., hlm. 5

${ }^{26}$ Ibid., hlm. 1

${ }^{27}$ Ibid., hlm. 2

${ }^{28}$ Ibid., hlm. 7
} 
biasanya akan merujuk masalah itu ke sistem peradilan; f. Jika ditetapkan denda berupa uang atau kompensasi, 10\% dari jumlah denda dibayarkan kepada damang sebagai biaya perkara; dan g. Kesepakatan tertulis diberikan juga kepada let adat atau kepala desa sebagai alat untuk memastikan ditaatinya kesepakatan tersebut.

Selain damang, di tingkat desa, berdasarkan rasa hormat serta popularitas pribadinya, kepala desa acap dilibatkan untuk menyelesaikan perselisihan. Sebagaimana diamati seorang penghulu. Masalah pidana ringan yang dapat diselesaikan dengan perdamaian biasanya dirujuk kepada ketua RT/RW, kepala adat atau kepala desa. ${ }^{29}$

\section{Penyelesaian Perkara Pidana Melalui Mediasi Pidana Pada Masyarakat Adat Aceh}

Di Aceh proses penyelesaian adat dapat berbeda-beda di masing-masing kabupaten atau daerah akan tetapi terdapat kesamaan cara atau metode dalam penyelesaian sengketa. Secara umum setiap kasus akan diajukan kepada geuchik, yang terlebih dahulu akan mendorong para pihak untuk membahas persoalan tersebut mencapai kompromi melalui musyawarah. Apabila para pihak tidak mencapai kompromi barulah geuchik dan para tetua gampong lainnya akan berusaha untuk menegosiasikan kesepakatan, dan membantu para pihak untuk mencapai kesepakatan bersama. Keterangan saksi diperlukan untuk membenarkan fakta, untuk itu kejujuran para pihak sangat penting untuk mencapai hasil penyelesaian yang adil.

Dalam bidang pidana ketentuan tentang qisas dan diyat disesuaikan dengan adat aceh. Penyesuaian ini misalnya sebagai berikut seratus onta dipahami sama dengan seratus ekor kerbau atau lembu, dan di dalam kenyataan hukum qisas tidak pernah dijatuhkan karena keluarga korban selalu memberikan pemaafan. Jumlah diyat walaupun pada dasarnya diakui seratus ekor lembu untuk pembunuhan sengaja, di dalam kenyataan sehari-hari pada umumnya dapat disetujui hanya dengan membayar beberapa ekor kerbau. Mengenai $t a^{\prime} z i r$ dijatuhkan melalui musyawarah pimpinan gampong, jarang yang sampai pada mahkamah yang waktu itu hanya ada pada tingkat pemerintahan uleebalang dan ibu kota kerajaan. Hukuman denda atau ganti rugi pengakuan bersalah dan meminta maaf secara resmi di muka umum, dicambuk dan diusir dari gampong merupakan bentuk-bentuk hukumannya. ${ }^{30}$

\footnotetext{
${ }^{29}$ Ibid., hlm. 10

${ }^{30}$ Al Yasa' Abubakar, "Islam, Hukum dan Masyarakat di Aceh Tajdid Syari'at Dalam Negara Bangsa”, Seminar: First International Conference of Aceh and Indian Ocean Studies, penyelenggara Asia Risearch Institute, National University of Singapore and Rehabilitation and Construction Executing Agency for Aceh and Nias (BRR), Banda Aceh, Indonesia. 24-27 Februari 2007, hlm. 3
} 
Terdapat empat pola penyelesaian konflik dalam tradisi masyarakat gampong di Aceh yaitu di'iet, sayam, suloeh dan peumat jaroe. Pola ini merupakan pola penyelesaian konflik yang menggunakan kerangka adat dan syari' at. ${ }^{31}$ Penyelesaian konflik dengan pola di'iet ditujukan untuk menghilangkan dendam dan rasa permusuhan berkepanjangan antara para pihak bertikai yang telah mengakibatkan kekerasan dan bahkan pembunuhan. Penyelesaian konflik yang terjadi dalam komunitas masyarakat gampong, baik yang bersifat individual atau internal keluarga, antar individu maupun antar kelompok, melalui bingkai adat dan agama, ternyata dapat membawa kepada kedamaian yang abadi dan permanen. ${ }^{32}$

Penyelesaian konflik melalui mekanisme di'iet, dilakukan pada penyelesaian kasus pembunuhan. Di'iet diwujudkan melalui kompensasi yang dibayarkan oleh pelaku pidana kepada korban atau ahli waris korban dalam kasus pembunuhan. Keuchik, teungku meunasah dan tetua gampong termasuk pemangku adat biasanya bertindak sebagai fasilitator, negosiator dan mediator dalam penyelesaian konflik melalui mekanisme di'iet. Mereka inilah yang melakukan pembicaraan-pembicaraan awal dengan ahli waris korban dan pelaku pidana atau ahli warisnya. Pelibatan keluarga besar dari para pihak menjadi sangat penting dalam pembicaraan tersebut, karena untuk menghindari dendam di kemudian hari. ${ }^{33}$

Keuchik, teungku meunasah dan tetua gampong memulai proses pemeriksaan kepada pelaku tindak pidana untuk dapat mengukur tingkat maaf yang diberikan oleh korban atau ahli waris korban. Jika pemaafan telah diberikan, maka para pemangku adat atau tetua gampong mengkompromikan atau bermusyawarah dengan pelaku atau ahli warisnya tentang jumlah di'iet yang harus dibayarkan oleh pelaku pidana. ${ }^{34}$

Selanjutnya, pelaku pidana atau keluarganya memberikan sesuatu, biasanya emas, kepada keluarga korban dan menyembelih hewan berupa sapi atau kerbau yang diprakarsai oleh imuem mukim, geuchik, dan teungku meunasah. Biasanya pembayaran di'iet dilakukan dengan suatu upacara adat yang didalamnya terdiri atas kegiatan peusijuek, $^{35}$

\footnotetext{
${ }^{31}$ Syahrizal dan Agustina Arida, "Pola Penyelesaian Konflik dalam Tradisi Masyarakat Gampong Aceh", Jurnal Seumikee, Volume II, 2006, Aceh Institute, hlm. 7.

${ }^{32}$ Ibid.

${ }^{33}$ Ibid.

${ }^{34}$ Ibid.

${ }^{35}$ Perangkat peusijuek berupa: nasi ketan kuning, kelapa gongseng gula merah (ue mierah), ayam panggang, tumpoe (tepung yang telah diaduk dengan gula merah yang digongseng), daun senijuek, daun ilalang (naleung samboe), padi dicampur beras, air tepung/air bunga, air putih, air cuci tangan dan kemenyan. Untuk penyelesaian kasus pembunuhan ditambah lagi dengan kain putih dan pedang/rencong di dalam sarung. Bahkan di beberapa daerah tertentu ditambah lagi dengan pemberian uang sekitar 2 juta sampai 5 juta rupiah.
} 
dan peumat jaroe. ${ }^{36}$ Keterlibatan institusi adat dan budaya dalam penyelesaian kasus pidana, bertujuan untuk menghilangkan dendam antara para pihak yang bertikai. ${ }^{37}$

Tempat upacara pembayaran di'iet biasanya digelar di meunasah, atau di rumah korban atau dapat pula diselenggarakan di tempat lain tergantung kesepakatan para pihak yang terlibat. Penyelesaian konflik melalui mekanisme sayam dilakukan pada penyelesaian kasus di luar pembunuhan seperti penganiayaan, atau pertengkaran yang menyebabkan luka, sehingga mengalirnya darah. Sama dengan di'iet, sayam juga menggunakan mekanisme kompensasi namun kompensasi yang diberikan berupa kambing atau yang setara dengan itu. ${ }^{38}$

Filosofi sayam bagi masyarakat Aceh bersumber dari adagium yang sudah dikenal lama yaitu "luka disipat, darah disukat". Makna adagium ini adalah luka akibat penganiayaan atau kekerasan harus diperhitungkan, demikian pula dengan tumpahnya darah juga harus diperhitungkan. Pandangan ini mengindikasikan bahwa masyarakat Aceh betul-betul memberikan penghargaan dan perlindungan yang tinggi terhadap tubuh manusia, sebagai ciptaan Allah. Sayam merupakan bentuk kompensasi yang bertujuan untuk melindungi dan memberikan penghormatan terhadap ciptaan Allah berupa tubuh manusia. Sama halnya dengan di'iet, prosesi sayam dilaksanakan setelah para pihak yang bersengketa atau bertikai dihubungi oleh keuchik dan teungku meunasah. Apabila kedua pihak telah bersepakat baru prosesi sayam dilaksanakan di rumah korban atau di meunasah. Mengingat sayam hanya ditujukan kepada tindak pidana yang bersifat ringan, namun menimbulkan luka atau keluar darah, maka peralatan dan bahan prosesi yang harus disiapkan

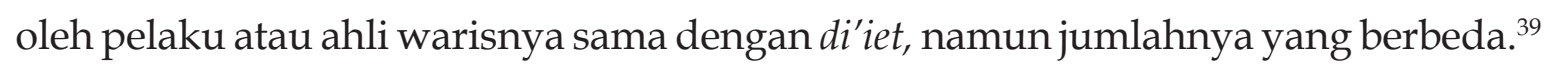

Penyelesaian konflik melalui mekanisme Suloh, merupakan pola penyelesaian konflik bukan hanya untuk kasus pidana, tetapi juga untuk kasus perdata atau sengketa dalam rumah tangga. Bahkan suloh merupakan dasar dari mekanisme penyelesaian konflik melalui di'iet dan sayam jika pengakhiran konflik diwujudkan dalam islah.

\footnotetext{
${ }^{36}$ Peumat jaroe, berjabat tangan. Dalam proses peumat jaroe, pihak yang menfasilitasi mengucapkan kata-kata khusus seperti: "Nyoe kaseb ob no dan bek na deundam le. Nyoe beujeut keujalinan silaturrahmi, karena nyan ajaran agama geutanyoe" yang artinya: Masalah ini cukup di sini dan jangan diperpanjang lagi. Bersalaman ini diharapkan menjadi awal dari jalinan silaturrahmi antara anda berdua, sebab ini ajaran agama kita.

${ }^{37}$ Ibid.

${ }^{38}$ Ibid.
} 
Penyelesaian kasus melalui peumat jaroe, merupakan bagian dari penyelesaian konflik dalam bentuk di'iet, sayam, suloeh. Pada mekanisme peumat jaroe umumnya digunakan untuk menyelesaikan kasus-kasus sangat ringan. Biasanya langsung dilakukan setelah terjadi konflik oleh para tetua adat yang menguasai daerah tertentu, tanpa sampai kepada keuchik atau teungku meunasah. Penyelesaian seperti ini biasanya untuk dan cukup dengan bersalam-salaman (peumat jaroe). ${ }^{40}$ Bentuk aktivitas adat dan budaya yang melekat pada di'iet, sayam dan suloeh adalah peusijuek dan peumat jaroe (saling berjabat tangan). Kedua institusi ini memegang peranan penting dalam menjalin rasa persaudaraan ( $u k h u w a h)$ antara para pihak yang bersengketa. ${ }^{41}$

\section{Penyelesaian Perkara Pidana Melalui Mediasi Pidana pada Masyarakat Adat Ambon}

Suatu perkara pidana ringan seperti perkelahian antar pemuda di lingkungan komunitas atau penganiayaan ringan dapat diselesaikan secara informal oleh komunitas setempat, Raja atau kepala desa mempunyai posisi sentral serta memiliki peranan dan pengaruh yang besar dalam penyelesaian sengketa informal. Raja menengahi dan membantu menyelesaikan berbagai persoalan dan kasus yang ada di masyarakat. Raja pula yang berhubungan dan berkoordinasi dengan pihak kepolisian dalam kasus-kasus pidana ringan atau sengketa tanah. ${ }^{42}$

Di komunitas Maluku, Raja dikenal sebagai pihak pemutus akhir dalam kasus atau sengketa yang sulit ditangani. ${ }^{43}$ Kepala Dusun juga bertindak sebagai mediator dalam sengketa perdata dan pidana ringan. Namun pada umumnya, penyelesaian sengketa mulai di tingkat yang terendah yakni melalui kepala soa dan ketua RT/ RW pada wilayah yang lebih urban seperti kota Ambon, kepala dusun kemudian Raja. Tujuan utama penyelesaian sengketa secara informal adalah untuk menjaga keharmonisan dan pemulihan relasi antara masyarakat dan agar penyelesaian kasus yang ada dapat menghemat biaya dan waktu para pihak yang bersengketa. Sayangnya, walaupun menjadi pilihan utama, mekanisme informal ini belum menjadi

${ }^{40}$ Ibid.

${ }^{41}$ Masyarakat Aceh menganggap belum sempurnanya penyelesaian konflik tanpa ada prosesi peusijuek dan peumat jaroe. Oleh karenanyaUpacara peumat jaroe disaksikan oleh banyak orang yang diundang pada acara kenduri dan peusijuek. Urutan kegiatan adalah peusijuek, peumat jaroe dan makan bersama (kenduri).

${ }^{42}$ Peri Umar Farouk, et al., "Mekanisme Penyelesaian Sengketa Informal di Kabupaten Buru, Kota Ambon dan Kabupaten Maluku Tengah", <http://www.justiceforthepoor.or.id/ documents/publikasi/vja-ambon.pdf>, diakses 17 Oktober 2007, 11:10

${ }^{43}$ Pengertian raja dalam hukum adat maluku adalah orang yang memimpin suatu Negeri atau Desa baik yang menduduki jabatan tersebut turun-menurun maupun dipilih secara Demokratis. Peri Umar Farouk, et al., "Mekanisme Penyelesaian Sengketa..." Ibid. 
bagian yang terintegrasi dari mekanisme atau sistem hukum yang didukung oleh pemerintah secara sungguh-sungguh.

Dalam keseharian dan dalam penyelesaian sengketa, seorang Raja dibantu oleh semacam dewan yang disebut sebagai "Saniri" di mana Raja sekaligus menjadi anggotanya. Apabila ada kasus yang diajukan kepada pihak Raja, maka Saniri akan memberikan dukungan baik dalam melakukan investigasi maupun dalam musyawarah yang dilakukan. Namun sebagian besar keputusan dan kata akhir tetap berada di tangan Raja.

Adapun urutan proses penyelesaian sengketa di tingkat komunitas sebagian besar mengikuti alur berikut: ${ }^{44}$ a. Pengaduan masuk ke pihak aktor penyelesai sengketa (misalnya Raja, tokoh agama atau tokoh masyarakat). Di tingkat desa atau Negeri, ada juga kasus yang diajukan ke Saniri Negeri terlebih dahulu sebelum diajukan ke pihak Raja; b. Apabila kasus adalah pidana berat, maka diajukan ke pihak Kepolisian; c. Para pihak dipanggil dan diwawancara dalam suatu pertemuan terbuka. Untuk tingkat desa/negeri, biasanya juga dihadiri oleh Saniri Negeri; d. Raja/tokoh agama/tokoh masyarakat kemudian menganalisa kasus dan hasil wawancara; e. Untuk kasus tanah, Raja akan meminta bantuan pihak Saniri terutama dalam melakukan investigasi; f. Raja memanggil para pihak untuk mengambil putusan sekaligus bernegosiasi mengenai sanksi nya. Apabila para pihak sepakat dengan hasil nya, maka biasanya ditulis suatu Berita Acara sederhana yang ditandatangani oleh para pihak; g. Apabila para pihak tidak puas terhadap proses penyelesaian yang ada, maka mereka dapat menempuh jalur pengadilan.

Proses penyelesaian dilakukan berdasarkan kesepakatan para pihak korban dan pelaku, hal ini ditegaskan oleh Raja Hative Kecil : “Kita harus minta persetujuan dari pihak korban". Hal yang sama juga disampaikan oleh Raja Asilulu, "Raja tidak bertindak seperti pengadilan, kita menggunakan pendekatan kekeluargaan. Namun himbauan saya jarang yang tidak dipatuhi oleh para pihak yang bersengketa" ${ }^{45}$

Raja berperan menjadi pendamai pihak yang bersengketa. Dengan demikian, harapannya setelah para pihak pergi dari rumah negeri atau rumah Raja, tempat di mana musyawarah dilakukan, maka komunitas setempat menjadi damai kembali. Dengan perkataan lain, kondisi komunitas yang terganggu akibat sengketa yang terjadi, kini telah dipulihkan.

\footnotetext{
${ }^{44}$ Peri Umar Farouk, et al., Loc. Cit.

${ }^{45}$ Ibid.
} 
Kasus Perkelahian akibat pelemparan mobil angkot di Dusun Ruhua - Desa Sepa, P. Seram - Kabupaten Maluku Tengah, kasus terjadi pada bulan Desember 2003, bermula dari pemuda Ruhua yang pergi memetik cengkeh tapi oleh masyarakat Desa Haya para pemuda tersebut disangka sebagai anggota masyarakat Tehoru. Sejak dulu masyarakat Haya punya masalah dengan masyarakat Tehoru. Orang Haya juga menduga bahwa Halue adalah orang Tehoru. Orang Haya sempat memukuli dan melempari orang-orang Ruhua yang memetik cengkeh ini. Untuk itu, Halue dan kawan-kawan membalas dengan menghentikan mobil angkutan kota yang dimiliki oleh orang Haya dan melempari kacanya dengan batu sampai pecah berantakan. Akibatnya orang Haya melaporkan persoalan ini ke pihak kepolisian. ${ }^{46}$

Selanjutnya pihak polisi memfasilitasi musyawarah untuk menyelesaikan persoalan ini. Di kantor polisi juga hadir Bapak Raja Sepa dan Sekretaris Desa. Bapak Raja memberikan nasihat untuk menyelesaikan kasus ini. di ujung musyawarah, para pihak diminta untuk membayar denda dan membuat surat pernyataan damai. Halue diminta membayar 500.000,00 (lima ratus ribu rupiah) sebagai bentuk ganti rugi kaca mobil yang telah dipecahkan. ${ }^{47}$ Kasus perkelahian antara tetangga di Desa Tamilou, P. Seram - Kabupaten Maluku Tengah, kasus bermula ketika seorang ayah yang kedua anaknya meninggal secara berturut-turut. Ayah menduga bahwa tetangga sebelahnya mempunyai andil atas kematian anaknya. Ia menganggap tetangga memiliki ilmu hitam sehingga menyebabkan kematian atas anaknya. ${ }^{48}$

Kasus sempat dibawa ke pihak polisi, namun ditarik kembali oleh aparat desa karena dianggap masih bisa diselesaikan sendiri. Musyawarah diadakan oleh pihak desa dan para pihak diminta membuat pernyataan damai. Pihak yang menuduh diminta untuk memberikan 1 bal kain putih ke pihak masjid. ${ }^{49}$

\section{Penyelesaian Perkara Pidana Melalui Mediasi Pidana Pada Masyarakat Adat}

\section{Lombok Utara}

Masyarakat Lombok Utara memiliki kepemimpinan adat yang dikenal sebagai adat Wet Tu Telu. Namun semenjak dikeluarkannya Undang-Undang Nomor 5 Tahun 1974 tentang Pemerintahan Daerah serta Undang-Undang Nomor 5 Tahun 1979

\footnotetext{
${ }^{46}$ Ibid.

${ }^{47}$ Ibid.

${ }^{48}$ Ibid.

${ }^{49}$ Ibid.
} 
tentang Pemerintahan Desa kepemimpinan adat Wet Tu Telu kehilangan eksistensinya. ${ }^{50}$

Inisiatif untuk mengembalikan eksistensi Wet Tu Telu, muncul seiring dengan diberlakukannya Undang-Undang Nomor 22 Tahun 1999 tentang Pemerintahan Desa, yakni dengan terbentuknya Persekutuan Masyarakat Adat Lombok Utara atau Perekat Ombara. Mereka mendeklarasikan keberadaannya di pertemuan besar (gundem) ke-5 tokoh-tokoh kepala desa dari 25 (dua puluh lima) desa di Lombok, 9 Desember 1999 di Desa Becingah, Kacamatan Bayan, Kabupaten Utara Lombok Barat. ${ }^{51}$

Awalnya gerakan Perekat Ombara ini merupakan wadah keprihatinan beberapa tokoh kepala desa yang memiliki kasus sama berkenaan dengan degradasi ekosistem hutan, yang diakibatkan eksploitasi perusahaan pemegang Hak Pengusahaan Hutan (HPH). Pertemuan-pertemuan selanjutnya, tidak saja hanya membicarakan masalah degradasi lingkungan, melainkan berkembang ke wacana revitalisasi adat budaya. Termasuk di dalamnya memunculkan upaya pembentukan model penyelesaian sengketa di luar institusi formal hukum yang dihadapi masyarakat. ${ }^{52}$

Berkenaan dengan prosesnya, penyelesaian sengketa di tingkat masyarakat belum ada aturan ketat tertentu. Meski diupayakan relevan dengan hierarki pemerintahan di desa yang diurutkan mulai yang terbawah dari RT/RW kemudian Dusun lalu Desa, namun pendekatan langsung ke tingkat yang lebih tinggi sangat terbuka, akan tetapi selalu ada himbauan terlebih dahulu untuk menyelesaikannya di tingkat yang lebih rendah, RT/RW atau Dusun. ${ }^{53}$

Kasus-kasus yang ditangani antara lain perkelahian atau pengeroyokan, hamil luar nikah, pemidangan (apel) kepada istri orang dan perzinahan. Umumnya perkara dilaporkan oleh pelaku pada kasus perkelahian atau pengeroyokan agar tidak terjadi balas dendam. Dalam kasus yang berhubungan dengan pergaulan laki-laki perempuan, inisiatif berasal dari Ketua RT/RW, pemuka masyarakat seperti penghulu, kiyai, atau mangku adat, atau tokoh pemuda. Pengaduan/laporan bisa diberikan secara tertulis maupun lisan. ${ }^{54}$

\footnotetext{
${ }^{50}$ Peri Umar Farouk, et. al, "Wet Tu Telu: Peluang Membangun Peradilan di Tingkat Desa", <http:// www.justiceforthepoor.or.id/documents/publikasi/vja-ntb.pdf > diakses 17 Oktober 2007, 11:15 WIB.

${ }^{51}$ Ibid.

${ }^{52}$ Ibid., Upaya penyelesaikan sengketa oleh masyarakat adat selaku mediator ada yang memformalkan menjadi bagian dari struktur pemerintahan di desa dan mengakuinya secara informal, yakni tanpa memasukkannya dalam struktur pemerintahan desa.

${ }^{53}$ Ibid., hlm 8

${ }^{54} \mathrm{Ibid}$., hlm. 9. Biasanya yang datang adalah orang yang berhubungan langsung dengan kasus, dengan didampingi oleh keluarganya atau yang dianggap sesepuh keluarga yang bersangkutan
} 
Penggalian informasi dari pihak pertama Pada kesempatan yang pertama informasi digali dari pengadu/pelapor atau orang yang diketahui mempunyai kasus. Di kesempatan ini, pihak yang diakses seperti RT/RW, Kadus, Kades, mempunyai hak diskresi untuk melibatkan orang lain atau tidak, terutama anggota Krama-nya (penghulu dan mangku adat) untuk mendengarkan keterangan pendahuluan. Pada kasus-kasus tertentu ada yang coba diselesaikan sendiri oleh RT/RW, Kadus, Kades tanpa melibatkan majelis yang lebih besar.

Penggalian informasi dari pihak lainnya atau pihak lawan dilakukan, kesempatan berikutnya, selang satu sampai tiga hari, mediator penyelesai sengketa mengundang pihak lain dalam kasus yang ditangani untuk didengar keterangan serta informasinya. Di kesempatan ini pihak yang diundang ditanyakan balik tentang versi dan konfirmasi sebagaimana pengaduan/laporan orang pertama.

Penggalian informasi dari saksi bilamana terdapat saksi atau pihak-pihak lain yang bisa menguatkan posisi kasus yang sedang ditangani, maka para saksi ini pun diundang untuk didengar keterangannya. Proses berkenaan dengan saksi sendiri bisa juga terjadi pada saat menggali keterangan dari pengadu/pelapor, saat mana para pengadu/pelapor membawa serta mereka dalam rangka menguatkan keterangannya. ${ }^{55}$

Mempertemukan para pihak di kesempatan ini masing-masing pihak menggemukkan secara terbuka persoalannya dan didengar langsung pihak lawannya. Di sessi ini juga bisa terjadi tanya jawab, saling mengkonfirmasi, bahkan saling silang pendapat. Di sessi ini juga semua kalangan yang berkaitan langsung dengan kejadian, seperti saksi, dihadirkan dan mengemukakan apa yang disaksikannya. Pertemuan para pihak ini lebih terfokus pada tuntutan yang dikehendaki satu pihak kepada pihak lainnya. Mediator akan memperhatikan layak tidaknya sebuah tuntutan satu pihak dipenuhi pihak lainnya.

Pendekatan pertama para aktor biasanya memposisikan diri terlebih dahulu sebagai orang yang meminta kesepakatan pihak satu dari tuntutan pihak lainnya. Di sini ia bertindak laksana negosiator atau konsiliator. Ia mengkomunikasikan atau menawarkan kehendak pihak yang menuntut untuk dipenuhi oleh pihak lainnya. Perkara-perkara kriminal ringan, dapat diselesaikan cepat, seperti perkelahian, pencurian. Dalam perkara-perkara tersebut polisi menyerahkan terlebih dulu penyelesaian kepada kepala tokoh adat lingkungan. ${ }^{56}$

\footnotetext{
${ }^{55}$ Ibid.

${ }^{56}$ Ibid., hlm. 10
} 


\section{Penyelesaian Perkara Pidana Melalui Mediasi Pidana pada Masyarakat Adat Lamaholot di Flores-Nusa Tenggara Timur}

Masyarakat lamaholot berpandangan untuk bisa menyelesaikan dengan baik kasus-kasus sengketa kriminal, institusi adat mela sareka difungsikan untuk memperbaiki relasi sosial yang rusak antara pihak. ${ }^{57}$ Proses ritual adat perdamaian mela sareka yaitu para pihak melakukan getun liko petin pepa atau pemisahan para pihak, karena ada konflik maka harus dipisahkan sehingga mereka yang berkonflik tidak boleh bertemu dan makan bersama jika dilanggar maka akan terkena risiko adat yaitu sakit, celaka atau meninggal. ${ }^{58}$ Ritual herun haban, acara untuk mempertemukan para pihak dan diakhiri dalam Bua Behin atau deklarasi hidup dalam damai, melalui makan minum bersama menandakan konflik telah hilang antara pelaku dan korban. ${ }^{59}$

Soba Sewalet ajakan damai, mediator adat dipilih dari orang-orang yang mempunyai pengaruh besar dalam suku atau kampung Pada pertikaian antar kampung maka tokoh adat yang akan menjadi mediator adalah tokoh adat netral yang tidak terlibat dalam perkelahian. Mediator akan mengupayakan gencatan senjata (leba rekat leu) menghasilkan perjanjian adat (nayu baya) agar dinamika masyarakat tidak terganggu. ${ }^{60}$ Uku loyak gatu gatan atau rekonstruksi kebenaran, pelaku tindak pidana berbicara dari hati ke hati untuk merekonstruksi kebenaran, pihak yang merasa paling bersalah wajib memohon kepada korban untuk melakukan perdamaian. ${ }^{61}$

Selanjutnya baik pelaku dan korban untuk menghapus segala kesalahan yang dilakukan oleh para pihak maka baik pelaku dan korban melakukan ritual adat haput ele kirin. Selanjutnya dilakukan ritual haput nuhuka bohok weweka untuk menghapus segala kesalahan yang dilakukan melalui kata-kata. Puncaknya dilakukan melalui mela sareka yaitu menuju dunia baru penuh damai sebagai puncak ritual. ${ }^{62}$

\section{Penutup}

Penyelesaian konflik antara pelaku tindak pidana dan korban tindak pidana dalam masyarakat adat di Indonesia, sebagaimana terdapat dalam masyarakat adat Banjar,

${ }^{57}$ Karolus Kopong Medan, "Peradilan Rekonsiliatif Konstruktif Penyelesaian Kasus Kriminal Menurut Tradisi Masyarakat Lamaholot, di Flores NTT", Disertasi, PDIH Undip, 2006, hlm 240.

${ }^{58}$ Ibid., hlm. 295-296

${ }^{59}$ Ibid.

${ }^{60}$ Ibid., hlm. 301

${ }^{61}$ Ibid., hlm. 303

${ }^{62}$ Ibid., hlm. 306 
masyarakat adat Dayak di Kalimantan Tengah, masyarakat adat Aceh, masyarakat adat Ambon, masyarakat adat Lombok Utara, masyarakat adat Lamaholot di Flores Nusa Tenggara Timur, menunjukkan kesamaan bentuk, yaitu adanya upaya perdamaian dan mengakhiri konflik dengan melibatkan pihak ketiga yang merupakan bentuk pendekatan mediasi pidana yang dikenal sebagai Traditional village or tribal moots. Penyelesaian hukum adat melalui upaya perdamaian tersebut dapat menjadi dasar bagi program mediasi modern, termasuk untuk mediasi pidana yang dapat dituangkan dalam peraturan perundang-undangan.

\section{Daftar Pustaka}

Abubakar, Al Yasa', “Islam, Hukum dan Masyarakat di Aceh Tajdid Syari' at Dalam Negara Bangsa", Seminar: First International Conference of Aceh and Indian Ocean Studies, penyelenggara Asia Risearch Institute, National University of Singapore and Rehabilitation and Construction Executing Agency for Aceh and Nias (BRR), Banda Aceh, Indonesia. 24-27 Februari 2007.

Bahruni, Ahmad, "Penyelesaian Tindak Pelanggaran Lalu-Lintas Secara Kekeluargaan, sebuah Tinjauan Menurut Hukum Islam dan Hukum Positif", dalam Ahmad Hasan, Penyelesaian Sengketa Hukum Berdasarkan Adat Badamai pada Masyarakat Banjar dalam Kerangka Hukum Nasional, Disertasi, Pascasarjana S3 Program Doktor Ilmu Hukum, Universitas Islam Indonesia, 2007.

Galanter, Marc., Keadilan di Berbagai Ruangan: Lembaga Peradilan, Penataan Masyarakat serta Hukum Rakyat dalam T.O. Ihromi (Penyunting), Antropologi Hukum sebuah Bunga Rampai, Yayasan Obor, Jakarta, 1993.

Gautama, Sudargo, "Penyelesaian Sengketa Secara Alternatif (ADR)," dalam Hendarmin Djarab, et al, (Editor), Prospek dan Pelaksanaan Arbitrase di Indonesia Mengenang Alm. Prof. Dr. Komar Kantaatmadja, S.H., LL.M., Citra Aditya Bakti, Bandung, 2001.

Hadikusuma, Hilman, Hukum Pidana Adat, Alumni, Bandung, tt.

Hafif, Jebar, Kamus Bahasa Banjar, Universitas Lambung Mangkurat Perss, Banjarmasin, 1999.

Hasan, Ahmad, "Penyelesaian Sengketa Melalui Upaya (Non-Litigasi) Menurut Peraturan Perundang-Undangan" dalam Jurnal Al-Banjari, Vol 5, No. 9, Januari-Juni 2007.

Hasan, Ahmadi, Penyelesaian Sengketa Hukum Berdasarkan Adat Badamai pada Masyarakat Banjar dalam Kerangka Sistem Hukum Nasional, Disertasi, Pascasarjana FH UII, 2007.

Juwariyah, Siti, Potret Mediasi dalam Islam, dalam http:/ / www.badilag.net, diakses 20 Desember 2009. 
Kartohadiprodjo, Sudiman, Hukum Nasional, Beberapa Catatan, Binacipta, Bandung, 1971.

Kopong Medan, Karolus, Peradilan Rekonsiliatif Konstruktif Penyelesaian Kasus Kriminal Menurut Tradisi Masyarakat Lamaholot, di Flores NTT, Disertasi, PDIH Undip, 2006.

Mahmud Marzuki, Peter, Penelitian Hukum, Kencana, Jakarta, 2005.

Mudzakkir, "Posisi Hukum Korban Kejahatan dalam Sistem Peradilan Pidana", Disertasi,: Program Pascasarjana FH UI, Jakarta, 2001.

Rekomendasi Dewan Eropa No R (99) 19.

Soekanto, Soerjono dan Sri Mamudji, Penelitian Hukum Normatif, Rajawali, Jakarta, 2010.

Sukanto, Suryono, "Pembahasan dalam Seminar Hukum Adat dan Pembinaan Hukum Nasional" dalam Imam Sudiyat, Peran Pendidikan dalam Pembangunan Hukum Nasional Berlandaskan Hukum Adat, Liberty, Yogyakarta, 1980.

Soekanto, Soerjono, Sosiologi Suatu Pengantar, Rajawali Pers, Jakarta, 1986.

Sudiyat, Imam, Peran Pendidikan dalam Pembangunan Hukum Nasional Berlandaskan Hukum Adat, Liberty, Yogyakarta, 1980.

Sulistiyo, Adi, Mengembangkan Paradigma Non-Litigasi di Indonesia, Sebelas Maret University Press, Surakarta, 2006.

Syahrizal dan Agustina Arida, "Pola Penyelesaian Konflik dalam Tradisi Masyarakat Gampong Aceh", Jurnal Seumikee, Volume II, 2006, Aceh Institute

Umar Farouk, Peri, et al., "Mekanisme Penyelesaian Sengketa Informal di Kabupaten Buru, Kota Ambon dan Kabupaten Maluku Tengah", <http:// www.justiceforthepoor.or.id/ documents/publikasi/vja-ambon.pdf $>$, diakses 17 Oktober 2007, 11:10

Umar Farouk, Peri, et, al, “Wet Tu Telu: Peluang Membangun Peradilan di Tingkat Desa", <http://www.justiceforthepoor.or.id/documents/publikasi/vjantb.pdf> diakses 17 Oktober 2007, 11:15 WIB.

"Kembali ke Masa Depan: Otonomi Daerah dan Kebangkitan Adat yang Tidak Pasti." hlm. 4 <http://www.justiceforthepoor.or.id/ documents/ publikasi/vja-kalteng.pdf>, diakses 17 Oktober 2007, 11:00 WIB.

Wright, Martin, sebagaimana dikutib oleh Marc Groenhuijsen, Victim-OffenderMediation: Lagal And Procedural Safeguards Experiments And Legislation In Some European Jurisdictions, Leuven, Oktober 1999. 